Article

\title{
Financial Inclusion and Firms Growth in Manufacturing Sector: A Threshold Regression Analysis in Selected Asean Countries
}

\author{
Rosmah Nizam, Zulkefly Abdul Karim* (D), Tamat Sarmidi and Aisyah Abdul Rahman \\ Center for Sustainable and Inclusive Development (SID), Faculty of Economics and Management, \\ Universiti Kebangsaan Malaysia (UKM), Bangi 43600, Malaysia; roses_173@yahoo.com (R.N.); \\ tamat@ukm.edu.my (T.S.); eychah@ukm.edu.my (A.A.R.) \\ * Correspondence: zak1972@ukm.edu.my
}

Received: 13 June 2020; Accepted: 24 August 2020; Published: 6 October 2020

check for updates

\begin{abstract}
This paper examines the effect of financial inclusion on the firm growth of the manufacturing sector (513 firms) in selected ASEAN countries (Malaysia, Philippines, and Vietnam) using a cross-section threshold estimation technique. The levels of financial inclusion across firms were measured based on the distribution of financial services (access to credit). The main findings revealed that there is a non-monotonic effect of financial inclusion on the firm's growth. These findings show that the impact of financial inclusion on firm growth in the manufacturing sector is significantly positive below a threshold point, and turns to significantly negative after a certain threshold point has been reached. These new findings suggest that manufacturing firm owners and banking institutions should deepen their financial inclusion efforts, and limit the distribution of credit access within the optimum value or threshold level in promoting the growth of the firm.
\end{abstract}

Keywords: financial inclusion; firm growth; threshold estimation

JEL Classification: O4; O47; C31; C18; C50

\section{Introduction}

Financial inclusion is an essential issue in development finance and is one of the dimensions of the quality of financial development. Financial inclusion entails the effective use of formal financial services by economic agents, including individuals and firms. In the case of this study, our focus is on firms, in which the financial inclusion measures by firms have a line of credit from a financial institution. Credit distribution across firms at the sector level has an essential influence on industrial structure, competition or unfairness in the sector, particularly in low-income countries (Beck et al. 2005). Access to credit reduces liquidity constraints, increases investment, and exerts a further impact on the industry structure and size of firms. For instance, credit obtained through financial institution loans is used to improve the flow of capital invested for the development and maintenance of fixed assets of a firm, such as property, building, factory, equipment and technology.

The study relating to the impact of financial inclusion on firm growth in Malaysia, Philippines and Vietnam is motivated by the report by the World Bank Enterprise Survey (WBES) in 2017. The report shows that these three countries hold the highest access to credit compared to firms in other countries globally, particularly those in the East Asian and Pacific regions. Access to credit, however, has been identified as one of the main obstacles to the development of the private sector in developing countries (Chauvet and Jacolin 2017). The growth of the East Asian economies and countries is traced to the benevolence of the financial institutions in this region granting credit to the private sector 
(Beck et al. 2012; Tchamyou and Asongu 2016). However, high access to credit does not necessarily guarantee the high sales growth of the firms. Therefore, this study will look into the threshold level of financial inclusion (access to credit) concerning firm manufacturing growth. To what extent the level of financial inclusion impacts a manufacturing firm's growth is one of the empirical questions we need to investigate further.

Manufacturing firms are of interest in this study because the WBES survey generally collects the data for this category of firms. Besides, manufacturing firms are involved in the real sector, and their performance will likely have a sporadic impact on the industrialization process of countries (Efobi et al. 2016). Therefore, micro-enterprises, informal enterprises, and those in the service sector like hotel services, transport services and Information and Communication Technology (ICT) provision are omitted from the analysis, as suggested by Clarke (2012).

Furthermore, there are no econometric studies that have analyzed the non-monotonic impact of financial inclusion on firm performance, with particular attention to the manufacturing firms in these countries. The empirical approach has used a cross-sectional data analysis rather than the traditional panel data approach due to the data availability of WBES (cross-section survey data). Thus, it is not possible to proceed with a panel data technique due to there being no yearly time frequency for the survey, and the firms differed across the survey period.

This paper contributes to the literature on the financial inclusion-growth nexus, and also to policymaking, in the following ways. First, the study extends the existing research by providing the non-monotonic relationship between financial inclusion and firm manufacturing growth. By providing new evidence on the impact of financial inclusion (FI) on a manufacturing firm's growth, this study will elucidate whether there exist threshold levels of financial inclusion in the firm's growth nexus. Thus, the threshold analysis has been used in obtaining the optimal level of financial inclusion that fosters a favorable effect on the firm's growth. Past literature, such as that by Chauvet and Jacolin (2017), has shown the linear relationship of financial inclusion and firm growth, whereas this study will extend the current literature by further investigating the issue of the nonlinearity relationship between financial inclusion and firm growth.

Second, this study contributes to the policy-making of manufacturing firms and financial institutions. The relationship between financial inclusion and the firm's growth may be contingent, whereby financial inclusion has a different effect on a firm's growth following its access to credit if it exceeds a certain threshold level. By knowing the contingent effect and appropriate financial inclusion threshold level, the firm owner and financial institutions will be able to limit the credit surplus to within the optimum level provided. Therefore, if there is clear evidence that a negative effect exists after a certain point of threshold level has been attained, then it provides new important policy implications, where the firm owner and financial institutions should devise an effective strategy and limit the distribution of credit access in fostering the firm's growth.

This paper is structured as follows. Section 2 provides a discussion on the literature review concerning financial inclusion as related to the firm's growth. Section 3 describes the data, the empirical model, and the econometric method. Section 4 discusses the empirical findings of the study. Finally, Section 5 provides a summary and conclusions.

\section{Literature Review}

Financial inclusion plays a positive role in improving the growth of a firm. Previous empirical studies have used financial development or financial deepening as a proxy in demonstrating its relationship with the growth. Studies on the impact of financial institution development on firms have concluded that there is a positive relationship. These studies are largely concentrated on understanding how financial institution development enhances a firm's ability to mobilize investment funds and reduce labor costs (Fafchamps and Schündeln 2013), innovation through the improvement of firms' productivity (Dabla-Norris et al. 2010), firms' sales and asset growth, as well as firms' sizes (Beck et al. 2004; Giannetti and Ongena 2009; Bas and Berthou 2012). 
Empirically, financial inclusions, which indicate the quality of financial development, are more significant in contributing to the firm's growth. Financial inclusion is universal access to financial products and services. A firm's access to some financial services may be of importance to its capital structure (Efobi et al. 2016). Credits channeled by financial institutions will increase the firm's capital, which will subsequently affect its growth. This condition will attract investors to increase the distribution of their credit funds, and will directly attract firms to access financial products such as loans, to boost the firm's growth. However, credit-funded investments do not generate significant net profit, but create assets through permanent investments from customers (Nwankwo and Ogonna 2014). According to Garg and Agarwal (2014), easy access to an efficient financial system by creating equal opportunities enables economists to contribute to the development and to protect themselves from the impact of economic shock.

International organizations (IMF Financial Access Survey and Findex Database) regularly survey access to credit as a measure of financial inclusion. During a global financial crisis, total deposits fall in an economy where financial inclusiveness is higher in terms of bank deposits, particularly for middle-income countries (Han and Melecky 2013). Such an outcome is advantageous to the government and private sector efforts in terms of boosting business in the financial sector through increasing access and the effective use of financial services to increase efficiency. In addition, a structural framework by Dabla-Norris et al. (2015) also showed that financial inclusion drives Gross Domestic Product (GDP) growth through access to credit, credit depth, as well as credit mediation efficiency among firms, in six countries studied (Malaysia, Kenya, Uganda, Philippines, Mozambique and Egypt).

A recent study by Chauvet and Jacolin (2017) on 55,596 firms in 79 developing and emerging countries showed that the distribution of financial services among firms had a positive impact on their growth. However, the study also took into account banking concentration, including suboptimal banking market conditions, in elucidating the effect of financial inclusion on a firm's growth. In their research, banks are more inclined to invest in information acquisition in a more concentrated market; however, in a highly comprehensive financial system, bank concentration harms the firm's performance. The findings show that bank concentration has a positive effect on firm growth for levels of financial inclusion lower than $85 \%$ of firms with a bank loan. Only 1093 firms out of the 55,596 belong to a sector with such a high level of financial inclusion. This positive effect of bank concentration (for levels of financial inclusion lower than 85\%) may appear counter-intuitive at first sight, since bank competition has various efficiency effects on credit markets where there is lower prices, better financial infrastructure and more financial inclusion.

In the past literature, credit distribution across firms at the sector level has also been shown to have an essential influence on industrial structure, competition and unemployment (Beck et al. 2005). However, credit access among firms needs to be controlled, as the impact of this excess credit may not significantly affect firm growth to some extent. The previous study by Huong Giang et al. (2019) and Fowowe (2017) argued that financial access has a positive effect (monotonic relationship) on firm growth. There is a possibility of financing unprofitable investment activities if access to finance is not controlled, whereby high economic freedom could affect firm growth. A high level of economic independence will cause business activities to be exposed to high risk and inefficiencies in business operations, and thus could affect firm growth.

Another study by Ina Ibor et al. (2017) in Nigeria concluded that there was a significant relationship between financial inclusion and the growth of large-scale SME firms, in which inclusive financial policies exerted a significant and positive impact on the operations of micro, small and medium enterprises. Some researchers have identified financial inclusion (for example, Beck et al. (2009)) as one of the solutions to the development of firms. In Koomson and Ibrahim (2017) showed that a non-farm firm's growth was boosted by $43 \%$ due to an increase in financial inclusion among entrepreneurs. Meanwhile, in India, Bas and Berthou (2012) noted that improved financial inclusion in terms of making credit accessible to firms would enhance firms' growth. 
Despite these important benefits and linear relationships of the financial access to firms' growth and productivity, some evidence suggests that the development of the financial sector may not necessarily lead to a positive growth outcome for firms (Asongu 2015). For instance, Arellano et al. (2008) observed that in less financially developed economies, small firms grow faster than large firms. Castelli et al. (2009) show evidence that Italian firms' performances decrease as the number of bank relationships increases, while Yazdanfar and Öhman (2015) concluded that firms relying on bank credit and debt are less profitable than their counterparts that do not rely on these credit facilities.

Furthermore, Thanh and Ha (2013) also found that Vietnamese firms which rely on a short-term credit financing relationship with banks are worse off, although the opposite direction has been seen for firms that depend on long term credit. Most of these contrary relationships have generally been theorized as caused by financial market imperfections, inadequate information, heightened transactions and contract enforcement costs, which are particularly prevalent in developing countries (Bigsten et al. 2000; Beck et al. 2004; Francis 2016; Tchamyou and Asongu 2016; Asongu et al. 2016). In these countries, businesses that lack collaterals, credit histories and interpersonal relationships with the bank could face the challenges of the impeded flow of capital, and even when they have access to this finance, the cost may outweigh any future benefit from it. To shed light on this emphasis, a growing financial inclusion (access to credit) may not necessarily reflect positive growth externalities for firms.

Therefore, this study was motivated to evaluate the extent to which the level of a firm's access to credit (financial inclusion) affects its growth. In the case of a manufacturing firm, the studies that relate to financial inclusion-growth are still limited in the literature. Most of the previous empirical studies (Zulfiqar et al. 2016; Dixit and Ghosh 2013) have entirely focused on individual or household access to financial services and the linearity effect of financial inclusion, which is an essential area of study. However, this study takes a different direction by considering manufacturing firms' access to financial services, determining the non-monotonic effect between the firm's access to credit and firm growth.

Given this backdrop, this study fills the gaps in the existing literature in three ways. First, it aims to examine the non-monotonic effect of financial inclusions on the growth of the manufacturing firms in Malaysia, the Philippines and Vietnam. Second, the study focuses on the current period wherein the data is based on the latest completed survey by WBES in 2015. Lastly, the study provides new evidence on the non-monotonic relationship of financial inclusion and the firm's growth. The past literature has identified monotonic relationships between financial inclusion and firm growth, whereas this paper extends the study to the non-monotonic effect of the financial inclusion-firm growth nexus.

\section{Methodology and Data}

\subsection{Data Description}

This study utilized cross-section firm-level data from Malaysia, Philippines and Vietnam (as listed in Table A1) in the Appendix A. The selection of firms was primarily dictated by the availability and reliability of the most current data (2015) obtained from the World Bank Enterprise Survey (2017). The dependent variables used in this study were the real annual average growth rate of sales over three years for each available survey, GROWTH $\mathrm{GR}_{i, k, j,-3}$, as a proxy variable for the firm's growth. Meanwhile, the independent variable (threshold variable) included financial inclusion as measured by the value of the most recent loans from a financial institution, $\mathrm{LOAN}_{i, k, j}$, as a firm's access to credit. The values of credit are initially recorded in the local currency unit (Ringgit (MYR), Peso (PHP) and Dong (VND)), but were converted to USD (USD) using the prevailing exchange rate as at the period of the survey (2015). We deemed this step as reasonable in order to enhance the comparability of the findings from our study.

Table 1 summarized the variables in modeling the determinants of manufacturing firm-growth. For explanatory variables, firm's characteristics have been considered in modeling the determinants of firm growth, as suggested by Chauvet and Jacolin (2017). These variables are as follows: (i) Credit 
access, the logarithm of recent loans from financial institutions (converted into USD), (ii) Initial sale, the logarithm of lagged sales $\left(\mathrm{SALES}_{i, k, j, t-3}\right)$ with the sales in the three previous years, deflated and converted into USD for catching-up effects; (iii) kind of ownership, including either owned by the state $\left(\mathrm{STATE}_{i, k, j}\right)$ or being a foreign entity $\left(\mathrm{FOREIGN}_{i, k, j}\right)$; (iv) Dummy variable of EXPORT $\mathrm{EX}_{i, k, j}$, which would be equal to one (1) if the firm exported part of its production either directly or indirectly; (v) Size of the firm (SIZE $\left.\mathrm{E}_{i, k, j}\right)$, which was categorized into three values; one (1) for small firms with less than 20 employees, two (2) when employees were between 20 and 100, and three (3) for firms with more than 100 employees.

Table 1. Measurements of Variables.

\begin{tabular}{|c|c|c|}
\hline Variables & $\begin{array}{l}\text { Acronyms/Proxies for } \\
\text { Model Estimation }\end{array}$ & Definition and Explanation \\
\hline Firm Growth & GROWTH & $\begin{array}{l}\text { Sales growth of the firm is between the completed } \\
\text { fiscal year and the previous three years. All sales } \\
\text { were (deflated) to } 2009 \text { using the GDP deflator of } \\
\text { each country. }\end{array}$ \\
\hline Credit Access & $L O A N$ & $\begin{array}{l}\text { Credit access is the logarithm of recent loans from } \\
\text { financial institutions (converted into USD). }\end{array}$ \\
\hline Initial Sales & SALES & $\begin{array}{l}\text { Initial sales are the logarithm of lagged sales; three } \\
\text { years' prior sales (deflated and converted into USD). }\end{array}$ \\
\hline State Ownership & STATE & $\begin{array}{l}\text { State ownership is defined as when part or all of the } \\
\text { firm was owned by the state (\%). }\end{array}$ \\
\hline Foreign Ownership & FOREIGN & $\begin{array}{l}\text { Foreign ownership is defined as when part or all of } \\
\text { the firm was owned by a foreign entity }(\%) \text {. }\end{array}$ \\
\hline Direct/Indirect Export & EXPORT & $\begin{array}{l}\text { Dummy variable, which was equal to one (1) when } \\
\text { the firm exports part of its production either directly } \\
\text { or indirectly (as a supplier of an exporting firm), } \\
\text { while it was equal to zero (0) when there was no } \\
\text { direct or indirect export transaction. }\end{array}$ \\
\hline Size of firm & SIZE & $\begin{array}{l}\text { Size refers to the category of variables that comprised } \\
\text { three values: one (1) when the firm was small } \\
\text { (less than } 20 \text { employees), two (2) when it employed } \\
\text { between } 20 \text { and } 100 \text { employees, and three (3) when } \\
\text { employees exceeded } 100 .\end{array}$ \\
\hline
\end{tabular}

\subsection{Model Specification and Empirical Strategy}

The empirical models based on Rajan and Zingales (1998), Chauvet and Jacolin (2017), and Nizam et al. (2020) were employed to explore the role of financial inclusion in the firm's growth. The econometric model took on the following form:

$$
\mathrm{GROWTH}_{i, k, j(t, t-3)}=\beta_{0}+\beta_{1} F I_{i, k, j}+\beta_{2} X_{i, k, j}+\varepsilon_{i}
$$

$G R O W T H_{i, k, j(t, t-3)}=$ sales growth for firm $i$ in industry $k$, country $j$. The average growth rates have been computed over three years, between $t$ and $t-3$.

$F I_{i, k, j}=$ Financial inclusion as measured by the firm's access to credit.

$X_{i, k, j}=$ vector of control variables that affect the sales growth for the firm, set of time-varying firm-level characteristics including the initial values of sales, ownership of the firm, the firm's export, and the size of the firm.

$\varepsilon_{i}=$ error term. 
There are two threshold effect hypotheses of nonlinearity in this study, namely:

$$
\begin{aligned}
& H_{0}: \beta_{1}=\beta_{2} \\
& H_{1}: \beta_{1} \neq \beta_{2}
\end{aligned}
$$

where $\beta_{s}$ are vectors of the parameter. The null hypothesis is linear regression, and the alternative hypothesis is nonlinear regression. If the null hypothesis is rejected, then we have a two-regime, nonlinear threshold regression. The following Equation (2) is particularly well suited to testing the hypothesis outlined, and to capturing the presence of contingency effects between financial inclusion and firm growth. The model based on threshold regression takes the following form:

$$
\text { Growth }_{i}=\left\{\begin{array}{cc}
\beta_{0}^{1}+\beta_{1}^{1} F I_{i}+\beta_{2}^{1} X_{i}+e_{i}, & F I_{i} \leq \gamma \\
\beta_{0}^{2}+\beta_{1}^{2} I F I_{i}+\beta_{2}^{2} X_{i}+e_{i}, & F I_{i}>\gamma
\end{array}\right\}
$$

where $F I_{i}$ (firm's access to credit) is the threshold variable used to split the sample into regimes or groups, and $\gamma$ is the unknown threshold parameter. This type of modeling strategy allows the role of financial inclusion to differ depending on whether the firms are below or above some unknown level of $\gamma$. In this equation, the firm's access to credit acts as a sample-splitting or threshold variable. The impact of financial inclusion on the firm's growth is designated $\beta_{1}^{1}$ and $\beta_{1}^{2}$ for firms with a low or high regime, respectively. On the other hand, under the hypothesis $\beta_{1}=\beta_{2}$, the model becomes linear and reduces to (1). Equation (2) can be re-written in a general form as:

$$
y_{i}=\beta_{1}^{\prime} x_{i} I\left(q_{i}<\gamma\right)+\beta_{2}^{\prime} x_{i} I\left(q_{i} \geq \gamma\right)+e_{i}=\beta_{1}^{\prime} x_{i}(\gamma)+e_{i}
$$

where $I($.$) is an indicator function,$

$$
\beta=\left(\beta_{1}^{\prime}, \beta_{2}^{\prime}\right) \text { and } x_{i}(\gamma)=\left[\begin{array}{l}
x_{i} I\left(q_{i}<\gamma\right) \\
x_{i} I\left(q_{i} \geq \gamma\right)
\end{array}\right]
$$

\subsection{Cross-Section Threshold Regression}

The first step in the estimation was to test the null hypothesis of linearity, $H_{0}: \beta_{1}=\beta_{2}$, against the threshold model in Equation (2). If the null hypothesis is rejected, then statistically, there is evidence of a threshold level of regression with two regimes, and the model is nonlinear. When there exists a threshold value, the sample is estimated to be $F I_{i} \leq \gamma$ in reference to the first regime and $F I_{i}>\gamma$ in reference to the second regime. The first regime is when the threshold level variable exceeds the threshold value. Statistically, both regimes give different decisions in terms of estimation.

This study adopted Hansen $(1996,2000)$ suggestion of using a heteroscedasticity-consistent Lagrange Multiplier (LM) bootstrap procedure to test the null hypothesis of a linear formulation against a threshold regression alternative. Since the threshold parameter $\gamma$ was not identified under the null hypothesis of the no-threshold effect, the $p$ values have been computed by a fixed bootstrap method. Hansen (2000) showed that this procedure yields asymptotically correct $p$ values. If the hypothesis of $\beta_{1}=\beta_{2}$ is rejected and a threshold level identified, then we test the threshold regression model against a linear specification after dividing the original sample according to the threshold level that is identified. This procedure was carried out repeatedly until the null of $\beta_{1}=\beta_{2}$ could no longer be rejected.

\section{Results and Discussion}

The impact of financial inclusion on the manufacturing firm's growth in Malaysia, Philippines and Vietnam is estimated using Equation (2). As mentioned previously, we employed a splitting sample threshold method from Hansen $(1996,2000)$ to investigate the threshold effect of financial inclusion as measured by the firm's access to credit. 
The descriptive statistics of the main variables of interest have been presented in Table 2, which contains the mean and standard deviations as well as a brief description. From the table, the average growth of the sampled firms is about $4.55 \%$. Concerning the measures of financial inclusion, the statistics show that $11.99 \%$ have access to a line of credit or loan.

Table 2. Statistic of firms in ASEAN-5 before Outliers.

\begin{tabular}{lccccc}
\hline \multicolumn{1}{c}{ Variables } & Measurement & Mean & SD & Min. & Max \\
\hline GROWTH $_{i, k, j(t, t-3)}$ & \% sales growth & 4.550 & 18.137 & -60.925 & 66.585 \\
LOAN $_{i, k, j}$ & Logarithm (USD) & 11.994 & 2.506 & 2.659 & 29.191 \\
SALES $_{i, k, j, t-3}$ & Logarithm (USD) & 8.977 & 1.986 & 1.836 & 15.140 \\
STATE $_{i, k, j}$ & \% Ownership & 1.865 & 9.478 & 0 & 80 \\
FOREIGN $_{i, k, j}$ & \% Ownership & 6.540 & 22.659 & 0 & 100 \\
EXPORT $_{i, k, j}$ & Dummy & 0.407 & 0.492 & 0 & 1 \\
SIZE $_{i, k, j}$ & Category & 2.057 & 0.744 & 1 & 3 \\
\hline
\end{tabular}

Note: Number of observation (N): 513 firms in the sample.

Based on the test of the null hypothesis of no threshold against the alternative hypothesis of a threshold allowing heteroskedastic errors (White corrected), Table 3 showed that the $p$-value of the hypothesis of no threshold effects, as computed by the bootstrap method with 5000 replications and 15\% trimming, was rejected at a highly significant level. These findings clearly indicate that the relationship between the firm's growth and financial inclusion is non-monotonic, and therefore the imposition of an a priori monotonic restriction on the relationship could also be ambiguous. The finding provides a better explanation for a dynamic relationship between financial inclusion and firm growth, where the former could effectively contribute to the growth of the firm at a certain level of threshold or at any of its interaction terms. We also tested further whether the group with high access to credit could be split further into sub-regimes. The bootstrap $p$-values were significant for the second sample split, which suggests that a double threshold is adequate for this model. However, we presented the empirical results for the first sample split in Table 4, while the results estimated for the second split are available upon request. The findings revealed several interesting observations.

Table 3. Threshold estimates of financial inclusion (Access to credit, $L O A N_{i, k, j}$ ).

\begin{tabular}{ccc}
\hline & First Sample Split & Second Sample Split \\
\hline LM test for no threshold & 30.916 & 16.206 \\
Bootstrap $p$-value & $0.000^{* * *}$ & $0.036^{* * *}$ \\
Threshold estimate & 13.541 & 17.577 \\
95\% confidence interval & {$[12.785,17.859]$} & {$[17.577,17.859]$} \\
\hline
\end{tabular}

Notes: ${ }^{* * *}$ significant at $1 \%$.

The result of the first sample split in Table 4 clearly showed the presence of the threshold level, which indicates that the sample can be split into two regimes depending on the level of access to credit in the firm.

The threshold model specifications in Table 4 show that above the threshold level $\left(L O A N_{i, k, j}>13.541\right)$, the coefficient of access to credit is significant and negatively affects firm growth. Therefore, above the threshold, a 13.541\% (USD 760,000), with a confidence interval in between $12.785 \%$ (USD 357,000) and $17.859 \%$ (USD 57 million), access to credit will decrease the firm's growth. Access to credit thus has a significant negative effect on the firm's growth after a certain threshold level has been attained. In our sample, 112 firms display access to credit above the threshold. The estimated coefficient of access to credit significantly harms the firm's growth. Thus, a 1\% increase in access to credit will decrease the firm growth by $2.540 \%$. Only the estimated coefficients of initial sales were significant determinants of a firm's growth at the $1 \%$ level. 
Table 4. First sample split: regression results using financial inclusion (FI-Loan) as a threshold variable. Dependent variable: firm growth (sales growth).

\begin{tabular}{|c|c|c|c|}
\hline Variable & $\begin{array}{l}\text { Linear Model OLS } \\
\text { without Threshold }\end{array}$ & $\begin{array}{c}\text { Regime 1 } \\
\operatorname{LOAN}_{i, k, j} \leq 13.541\end{array}$ & $\begin{array}{c}\text { Regime 2 } \\
\operatorname{LOAN}_{i, k, j}>13.541\end{array}$ \\
\hline \multirow{2}{*}{ Constant/Intercept } & $19.198^{* * *}$ & $15.373^{* * *}$ & $65.846^{* * *}$ \\
\hline & $(4.951)$ & $(6.295)$ & $(16.362)$ \\
\hline \multirow{2}{*}{$L O A N_{i, k, j}$} & $1.213 * *$ & $2.786^{* * *}$ & $-2.540 * * *$ \\
\hline & $(0.619)$ & $(0.645)$ & $(0.699)$ \\
\hline \multirow{2}{*}{$S A L E S_{i, k, j, t-3}$} & $-4.625^{* * *}$ & $-6.461^{* * *}$ & $-2.385^{* * *}$ \\
\hline & $(0.640)$ & $(0.659)$ & $(0.859)$ \\
\hline \multirow{2}{*}{$\operatorname{STATE}_{i, k, j}$} & 0.072 & $-0.149 *$ & 0.125 \\
\hline & $(0.077)$ & $(0.078)$ & $(0.084)$ \\
\hline \multirow{2}{*}{ FOREIGN $_{i, k, j}$} & -0.026 & -0.015 & -0.046 \\
\hline & $(0.028)$ & $(0.035)$ & $(0.035)$ \\
\hline \multirow{2}{*}{$\operatorname{EXPORT}_{i, k, j}$} & $-3.121 *$ & $-4.669^{* * *}$ & 3.503 \\
\hline & $(1.609)$ & $(1.803)$ & $(2.711)$ \\
\hline \multirow{2}{*}{$S I Z E_{i, k, j}$} & $6.626^{* * *}$ & $7.459 * * *$ & 1.262 \\
\hline & $(1.276)$ & $(1.410)$ & $(2.559)$ \\
\hline R-square & 0.134 & 0.231 & 0.236 \\
\hline Heteroscedasticity test ( $p$-value) & 0.396 & - & - \\
\hline No. of Observation & 513 & 401 & 112 \\
\hline Sum of squared residuals & $145,910.210$ & $108,572.661$ & $20,739.677$ \\
\hline
\end{tabular}

On the other hand, below the threshold level $\left(\operatorname{LOAN}_{i, k, j} \leq 13.541\right)$, with confidence interval [12.785, 17.859], the coefficient is significant and positive in influencing the firm's growth. As such, the growth has been shown to be positively correlated with its access to credit, $\operatorname{LOAN}_{i, k, j,}$, where a $1 \%$ increase in access to credit will increase firm growth by $2.786 \%$. All the estimated coefficients were significant determinants of a firm's growth, except in the case of foreign ownership, where it is an insignificant determinant irrespective of the level of inclusion threshold. Similarly, the size of the firm was positively associated with the firm's growth regardless of the threshold level. Larger firms with high credit access thus experience better performance, while the value of initial sales in the previous three years, $t-3$, showed a negative effect on the firm's growth irrespective of the threshold level. Firms that showed a low level of sales in $t-3$ displayed better growth or performance. This thus shows that initial sales are significant in influencing growth in both the regimes of the models.

Figure 1 displays a graph of the normalized likelihood ratio sequence, $L R_{n}^{*}(\gamma)$, as a function of the threshold output. The LS estimate of $\gamma$ in Figure 1 is the value that minimizes the graph, which at its minimum occurs at $\hat{\gamma}=13.541$. The $95 \%$ critical value (dotted line) shows the asymptotic $95 \%$ confidence interval from the graphs, where $L R_{n}^{*}(\gamma)$ crosses the dotted line. The results indicate reasonable evidence for a two-regime specification. Among the 513 firms with initial output above 13.541 , a sample split based on the firm's access to credit is shown to be significant at the $1 \%$ level, with a $p$-value of 0.00 . The findings suggest a possible threshold effect in the access to credit that further split these two subsamples. The results of the bootstrap test statistics were shown to be significant at the $1 \%$ level. 


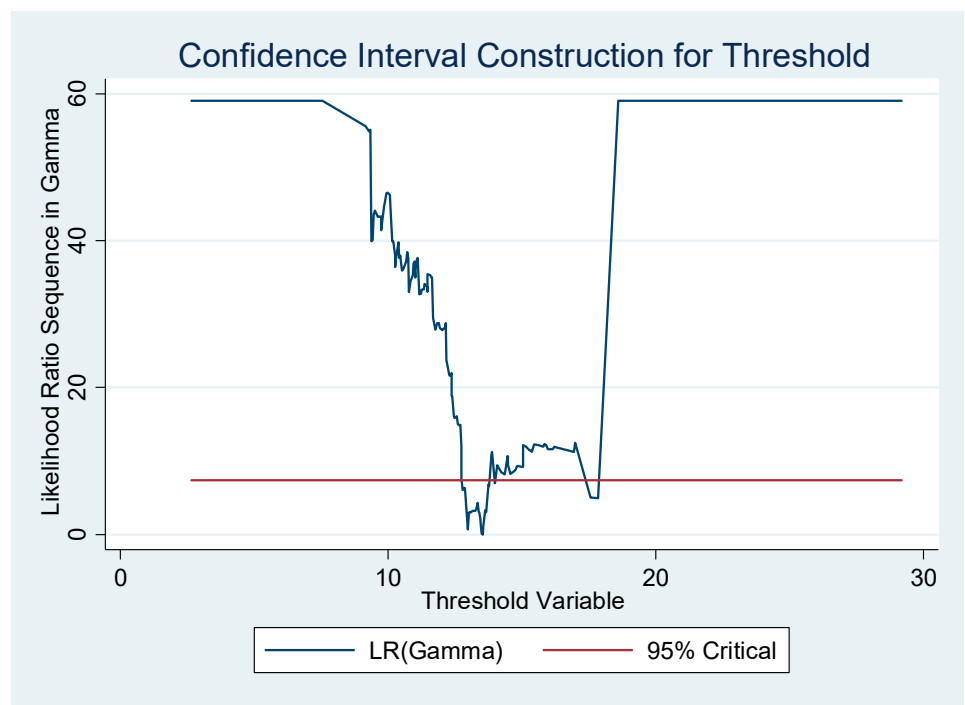

Figure 1. First sample split: confidence interval construction for threshold. Threshold variable: access to credit, $\operatorname{LOAN}_{i, k, j}$.

\section{Summary and Conclusions}

This study provides new evidence of the nonlinearities associated with the impact of financial inclusion (access to credit) on the firm's growth (513 manufacturing firms sampled) in Malaysia, Philippines and Vietnam. The cross-section model based on the concept of the threshold effect proposed by Hansen (2000) was used to capture the relationship between financial inclusion and the firm's growth. The empirical results indicate that there is a significant financial inclusion threshold in the financial inclusion-firm's growth nexus. The threshold point tests the different effects of financial inclusion on firm growth with comparisons made between a low level of credit access and a high level of credit access.

The main empirical results of the cross-section threshold regression can be summarized in two conclusions: First, there is a threshold effect in the relationship between financial inclusion and the firm's growth, which was within expectations. Below this threshold level, financial inclusion should foster a significantly positive effect on a firm's growth. However, above the threshold level, the impact of financial inclusion was significantly negative. As such, an a priori monotonic restriction on the analysis of the financial inclusion-firm's growth nexus, as reported in the past literature, such as Chauvet and Jacolin (2017), could lead to a premature conclusion. However, this study presents a new finding on the non-monotonic relationship in the nexus. Second, we introduced new evidence whereby financial inclusion (access to credit) contributes to the negative effect of the firm's growth after a certain threshold level has been reached. Thus, the firm's owners and the financial institutions in these countries need to control the value of the credit access of the firms, since higher access to credit, above the threshold level of the confidence interval, will exert a negative effect on the firm's growth, particularly for those in the manufacturing sector.

These findings, therefore, underline the importance for firm owners and financial institutions to focus on the optimal value of the credit access of the firms, so as to ensure their higher performance. Financial inclusiveness exhibits a non-monotonic relationship with the firm's growth. The further expansion of access to credit above the threshold level would significantly decrease the firm's growth. The findings thus underline the importance of policymakers or banking institutions determining the level of access to credit among firms so as to ensure credit surplus above the threshold level will not confer adverse effects on their growth. Based on this study, the threshold value of credit access for the firms in the manufacturing sector is USD 760,000, with a confidence interval of USD 357,000 for firms with lower access to credit and USD 57 million for firms with high access to credit. A firm's owners and financial institutions in the developing economies must control the value of credit access, since 
an access level higher than the threshold of the confidence interval will exert a negative effect on the firm's growth.

This study identified several possibilities for future research. Beyond access to credit, other relevant variables can be considered as proxies and measurements of financial inclusion in its analysis, like working capital with bank credit and overdraft facility. Different financial inclusion indicators may respond differently and react rigorously. Due to the limitation of available data in these countries, future research should consider using the index as a proxy of financial inclusion across firms, and a large panel dataset to capture the broader perspectives on the relationship between financial inclusion and firm growth. Other measures of firm growth as an explained variable could also include some accounting ratios (return on assets of the firm, or even investment ratios) to measure the performance of the firm.

Author Contributions: R.N. carried out the experiment, wrote, and revised the manuscript with support from Z.A.K., T.S. and A.A.R. The central idea of this research, is given by R.N. and Z.A.K. The earliest manuscript is verified by Z.A.K., T.S., and A.A.R. Z.A.K. and T.S. have also verified the analytical method and the interpretation of the results of this article. Z.A.K. supervises the revised version of this article as a correspondence author. All authors have contributed significantly from the earlier draft until the final stage of the manuscript. All authors have read and agreed to the published version of the manuscript.

Funding: This research received no external funding.

Conflicts of Interest: The authors declare no conflict of interest.

\section{Appendix A}

Table A1. List of countries and number of observations: manufacturing firms in Malaysia, Philippines and Vietnam.

\begin{tabular}{cc}
\hline Countries & Number of Firms (513 firms) \\
\hline Malaysia & 88 \\
Philippines & 139 \\
Vietnam & 286 \\
\hline
\end{tabular}

\section{Estimation Procedures:}

The setup of the LM test results for no threshold, reported in Table 3: Stata command 'thresholdtest' computes a test for a threshold in linear regression, allowing for heteroscedasticity. In Stata, to run the model, the standard syntax is 'thresholdtest y $x, \mathrm{q}(\mathrm{z})$ trim_per $(\mathrm{p}) \operatorname{rep}(\mathrm{R})$ '.

The inputs are:

$\mathrm{y}=$ dependent variable

$\mathrm{x}=$ independent variable

$\mathrm{z}=$ threshold variable

$\mathrm{p}=$ percentage of sample to trim from ends, e.g., $p=0.15$ (default value if option omitted) trimming

proportion to estimate each threshold

$\mathrm{R}=$ number of bootstrap, e.g., $\mathrm{R}=5000$ (default value if option omitted)

Therefore, the command for testing the presence of the threshold is:

thresholdtest growth lloanus ln3us b2cstate b2bforeign exportdummy sizecategory, q(lloanus) trim_per(0.15) rep(5000)

This study did not test for the presence of possible multiple thresholds, since the cross-section threshold regression tests the null hypothesis of linearity $H_{0}: \beta_{1}=\beta_{2}$ against the threshold model of Growth $_{i}=\left\{\begin{array}{cc}\beta_{0}^{1}+\beta_{1}^{1} F I_{i}+\beta_{2}^{1} X_{i}+e_{i}, & F I_{i} \leq \gamma \\ \beta_{0}^{2}+\beta_{1}^{2} I F I_{i}+\beta_{2}^{2} X_{i}+e_{i}, & F I_{i}>\gamma\end{array}\right\}$.

The $p$-value is computed by a fixed bootstrap method. Hansen (2000) shows that this procedure yields asymptotically correct $p$-values. 
For Figure 1, the Stata command 'thresholdreg' computes estimates and confidence intervals for the threshold models. The standard syntax in Stata is 'threhsoldreg y $x, \mathrm{q}(\mathrm{z}) \mathrm{h}(\mathrm{ind})$ '. The inputs are:

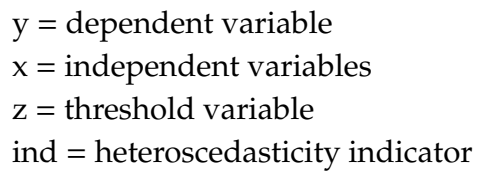

Therefore, in this study, the thresholdreg syntax is:

thresholdreg growth lloanus ln3us b2cstate b2bforeign exportdummy sizecategory, q(lloanus) h(1) The program estimates a threshold regression, and prints the results to the screen. The program also plots a graph of the likelihood ratio process in the threshold, useful for threshold confidence interval construction.

\section{References}

Arellano, Cristina, Yan Bai, and Jing Zhang. 2008. Firm Dynamics and Financial Development. Available online: http://crei.cat/activities/crei_seminar/08-09/arellano.pdf (accessed on 27 January 2020).

Asongu, Simplice A. 2015. Finance and Growth: New Evidence on Meta-Analysis. Managerial Finance 41: 615-39. [CrossRef]

Asongu, Simplice A., Jacinta C. Nwachukwu, and Vanessa S. Tchamyou. 2016. Information Asymmetry and Financial Development Dynamics in Africa. Review of Development Finance 6: 128-36. [CrossRef]

Bas, Maria, and Antoine Berthou. 2012. Financial Development in India and Firm's Growth. Paris: CEPII.

Beck, Thorsten, Asli Demirgüç-Kunt, and Vojislav Maksimovic. 2005. Financial and Legal Constraints to Growth: Does Firm Size Matter? Journal of Finance 60: 137-77. [CrossRef]

Beck, Thorsten, Asli Demirgüç-Kunt, and Patrick Honohan. 2009. Access to Financial Services Measurement, Impact, and Policies. World Bank Research Observer 24: 119-45. [CrossRef]

Beck, Thorsten, Asli Demirgüç-Kunt, Luc Laeven, and Ross Levine. 2004. Finance, Firm Size, and Growth. NBER Working Paper. Washington, DC: The World Bank, p. 10983.

Beck, Thorsten, Berrak Büyükkarabacak, Felix K. Rioja, and Neven T. Valev. 2012. Who gets the credit? And Does It Matter? Household vs. Firm Lending Across Countries. The BE Journal of Macroeconomics 12: 1-46.

Bigsten, Arne, Paul Collier, Stefan Dercon, Marcel Fafchamps, Bernard Gauthier, Jan Willem Gunning, Abena Oduro, Remco Oostendorp, Cathy Patillo, Måns Söderbom, and et al. 2000. Credit Constraint in Manufacturing Enterprises in Africa. Journal of African Economies 12: 104-25. [CrossRef]

Castelli, Annalisa, Gerald P. Dwyer, and Iftekhar Hasan. 2009. Bank Relationships and Firms' Financial Performance: The Italian Experience. European Financial Management 18: 28-67. [CrossRef]

Chauvet, Lisa, and Luc Jacolin. 2017. Financial Inclusion, Bank Concentration, and Firm Performance. World Development 97: 1-13. [CrossRef]

Clarke, George. 2012. Manufacturing Firms in Africa: Some Stylized Facts about Wages and Productivity. In Performance of Manufacturing Firms in Africa: An Empirical Analysis. Edited by Dinh Hinh T. and Clarke George R. G. Washington, DC: World Bank, pp. 47-83.

Dabla-Norris, Era, Erasmus K. Kersting, and Geneviève Verdier. 2010. Firm Productivity, Innovation, and Financial Development. Southern Economic Journal 79: 422-49. [CrossRef]

Dabla-Norris, Ms Era, Yan Ji, Robert Townsend, and D. Filiz Unsal. 2015. Identifying Constraints to Financial Inclusion and Their Impact on GDP and Inequality. IMF Working Paper. Washington, DC: International Monetary Fund.

Dixit, Radhika, and Munmun Ghosh. 2013. Financial Inclusion for Inclusive Growth of India-A Study of Indian States. International Journal of Business Management \& Research (IJBMR) 3: 147-56.

Efobi, Uchenna Rapuluchukwu, Voufo Belmondo Tanankem, and Ibukun Beecroft. 2016. Incentives and Firms' Productivity: Exploring Multidimensional Fiscal Incentives in a Developing Country. World Development Perspectives 5: 56-59. [CrossRef]

Fafchamps, Marcel, and Matthias Schündeln. 2013. Local Financial Development and Firm Performance: Evidence from Morocco. Journal of Development Economics 103: 15-28. [CrossRef]

Fowowe, Babajide. 2017. Access to finance and firm performance: Evidence from African countries. Review of Development Finance 7: 6-17. [CrossRef] 
Francis, David. 2016. Financial Development Helps the Poor in Poor Countries. Cambridge: NBER.

Garg, Sonu, and Parul Agarwal. 2014. Financial Inclusion in India: A Review and Initiatives and Achievements. IOSR Journal of Business and Management 16: 52-61. [CrossRef]

Giang, Mai Huong, Bui Huy Trung, Yuichiro Yoshida, Tran Dang Xuan, and Mai Thanh Que. 2019. The Causal Effect of Access to Finance on Productivity of Small and Medium Enterprises in Vietnam. Sustainability 11: 5451. [CrossRef]

Giannetti, Mariassunta, and Steven Ongena. 2009. Financial Integration and Firm Performance: Evidence from Foreign Bank Entry in Emerging Markets. Review of Finance 13: 181-223. [CrossRef]

Han, Rui, and Martin Melecky. 2013. Financial Inclusion for Financial Stability: Access to Bank Deposits and the Growth of Deposits in the Global Financial Crisis. Policy Research Working Paper. Washington, DC: World Bank, p. 6577.

Hansen, Bruce E. 1996. Inference when a Nuisance Parameter is not Identified under the Null Hypothesis. Econometrica 64: 413-30. [CrossRef]

Hansen, Bruce E. 2000. Sample splitting and Threshold Estimation. Econometrica 68: 575-603. [CrossRef]

Ibor, Bassey Ina, Amenawo Ikpa Offiong, and Enyeokpon Samuel Mendie. 2017. Financial Inclusion and Performance of Micro, Small and Medium Scale Enterprises in Nigeria. International Journal of Research Granthaalayah 5: 2394-3629.

Koomson, Isaac, and Muazu Ibrahim. 2017. Financial inclusion and Growth of Non-Farm Enterprises in Ghana. In Network for Socioeconomic Research and Advancement Working Paper. Biddeford: University of New England.

Nizam, Rosmah, Zulkefly Abdul Karim, Aisyah Abdul Rahman, and Tamat Sarmidi. 2020. Financial inclusiveness and economic growth: New evidence using a threshold regression analysis. Economic Research Ekonomska Istraživanja 33: 1465-84. [CrossRef]

Nwankwo, Odi, and Nwankwo Ogonna. 2014. Sustainability of Financial Inclusion to Rural Dwellers in Nigeria: Problems and Way Forward. Research Journal of Finance and Accounting 5: 24-31.

Rajan, Raghuram G., and Luigi Zingales. 1998. Financial Dependence and Growth. American Economic Review 88: 559-86.

Tchamyou, Vanessa S., and Simplice A. Asongu. 2016. Information Sharing and Financial Sector Development in Africa. Journal of African Business 18: 24-49. [CrossRef]

Thanh, Vu Huu, and Nguyen Minh Ha. 2013. The Effect of Banking Relationship on Firm Performance in Vietnam. International Journal of Economics and Finance 5: 148-58. [CrossRef]

World Bank Enterprise Survey (WBES). 2017. Washington, DC: The World Bank Country Survey.

Yazdanfar, Darush, and Peter Öhman. 2015. Debt Financing and Firm Performance: An Empirical Study Based on Swedish Data. The Journal of Risk Finance 16: 102-18. [CrossRef]

Zulfiqar, Kalsoom, Muhammad Aslam Chaudhary, and Aribah Aslam. 2016. Financial Inclusion and Its Implications for Inclusive Growth in Pakistan. Pakistan Economic and Social Review 54: 297-325. 